\title{
A DNA extraction method used for evaluation of diversity of the plant rhizosphere microbial community
}

\author{
Jinbin Wang ${ }^{1,2}$, Guogan $\mathrm{Wu}^{1,2}$, Wen $\mathrm{Li}^{2}$, Kai Zhao ${ }^{1,2}$, Ziping $\mathrm{Zhu}^{2}$, Hua Liu ${ }^{1,2}$, Peng $\mathrm{Li}^{1,2}$, Lan \\ Bai $^{1,2}$, Manman Wei ${ }^{1,2}$, Aihu Pan ${ }^{1,2}$, Beibei Lü ${ }^{1,2}$ and Xueming Tang ${ }^{1,2,3 *}$ \\ ${ }^{1}$ Biotechnology Research Institute, Shanghai Academy of Agricultural Sciences, 2901 Beidi Road, Shanghai, 201106, \\ The People's Republic of China. \\ ${ }^{2}$ Key Laboratory of Agricultural Genetics and Breeding, Shanghai Academy of Agricultural Sciences, 2901 Beidi Road, \\ Shanghai, 201106, The People's Republic of China. \\ ${ }^{3}$ Supervision, Inspection and Test Center for Environmental Safety of GM Crops of MOA (Shanghai), 2901 Beidi Road, \\ Shanghai, 201106, The People's Republic of China.
}

Accepted 17 May, 2013

\begin{abstract}
An effective method for plant rhizosphere microbial genomic DNA extraction was established. Highpurity nucleic acids extracted from soil samples, with considerable yield, could be used for study of soil microorganism molecular ecology. Genomic DNAs were extracted from 12 soil samples of different crop roots. Above $10 \mu \mathrm{g}$ of genomic DNA with approximately $20-\mathrm{kb}$ fragment length was isolated from 1 $\mathrm{g}$ of soil sample. The average value of A260/A230 of the genomic DNA was 1.505, while that of A260/A280 was 1.780. The absorption curves of the full wavelengths of the DNA extracted were consistent with that of pure nucleic acid. DNAs from different dilutions of pollutants were applicable for restriction enzyme digestion analysis, and the lambda DNA in 100-fold diluted soil samples had the same restriction enzyme digestion results as done in ddH2O. Amplicons was produced with the expected molecular size by polymerase chain reaction (PCR).Therefore, the DNA extracted by this method was suitable to be used in analysis of bacterial ecology composition by denaturing gradient gel electrophoresis.
\end{abstract}

Key words: DNA extraction, DNA quality, PCR amplification, soil microbial community diversity, DGGE.

\section{INTRODUCTION}

Soil is a complex environment, and is a major reservoir of microbial genetic diversity (Robe et al., 2003). Soils and their microbial inhabitants are critical to global biogeochemical cycles including carbon, nitrogen and phosphorus, which support all other forms of terrestrial diversity. Because of their importance on multiple levels, soils have been the subject of studies in microbial ecology for decades (Borneman and Triplett, 1997; Nunanet al., 2003; Skinner et al., 1952; Skyring and Quadling, 1969; Steffanet al., 1988; Waksman and Woodruff, 1940; Williamson et al., 2010). The complexity of microbial diversity results from multiple interacting parameters, including $\mathrm{pH}$, water content, soil structure, climatic variations and biotic activity. In recent years,

^Corresponding author: E-mail: happyhundan@tom.com

Abbreviations: GM, Genetically modified; Bt, Bacillus thuringiensis; DGGE, denaturing gradient gel electrophoresis; PCR, polymerase chain reaction; EB,ethidium bromide; PVPP,polyvinylpolypyrrolidone; EDTA, ethylene diamine tetra-acetic acid; SDS, sodium dodecyl sulphate. 
the use and release of genetically modified (GM) plants has been an issue of intense public concern. The global area of GM crops increased approximately 100-fold during the 18-year period from 1.7 to 170 million hectares (James, 2013). Two main focus of concern have emerged: risk to the environment and to human health. Despite the large area of Bacillus thuringiensis $(\mathrm{Bt})$ crops and herbicide tolerant $(\mathrm{HT})$ crops planted, there are still scientifically interesting issues to be researched with regard to the little-known soil compartment. Microbial community structure and function in rhizosphere soil, which is directly influenced by root exudates of GM plants, are often proposed as an early and dynamic indicator of GM risk assessment on soil ecology, and used increasingly for sensitive responses. The type and amount of nutrients released by plants will affect both the numbers of organisms and their diversity, for example, insecticidal Cry proteins derived from insect-resistant $\mathrm{Bt}$ crops in soils through cultivation of Bt crops (Atwood, 2011; Birch et al., 2007; Dauduet al., 2009; Dunfield and Germida, 2001; Griffiths et al., 2007; Groot and Dicke, 2002; Heckmannet al., 2006; Höss et al., 2011).

Soils are home to a diverse range of life, which are complex and dynamic biological systems (Stotzky, 1997). Therefore, it is often difficult to determine the composition of microbial communities in soil and their response to perturbations of this ecosystem. However, even small changes in the composition of the microbial community should be considered early warning indicators for risk assessment. Although recent methodological advances, especially molecular techniques, are helping in the understanding of soil communities, many aspects of these communities are still not sufficiently understood (Kowalchuket al., 2003). Therefore, the taxonomy based on phylogeny, in which data from uncultured bacteria are included, is rapidly changing and replacing the former taxonomy based exclusively on morphological, physiological and biochemical parameters of cultured bacteria (Garrity, 2005). In environmental safety evaluation systems of GM plants, the application of environmental microbial metagenome molecular finger-printing (for example, denaturing gradient gel electropho-resis, DGGE) is currently a key technology in researching the soil microbial community diversity of plant roots. Molecular techniques and genetic studies require a fair amount of high quality DNA to produce reliable and clear results (Li et al., 2007). Efficient extraction of target DNA is the crucial first step in any DNA-based analysis of soil microbes, however, the yield and quality of DNA from soil can be significantly affected by secondary metabolites such as humic compounds. Humic acids have physicochemical properties similar to nucleic acids, therefore, humic substances along with the adsorbed organic molecules are generally co-extracted with DNA. Humic acids affect almost all molecular biological methods such as hybridization, restriction digestions of DNA, polymerase chain reaction (PCR) and bacterial transformation
(Tebbe and Vahjen, 1993). Therefore, in most metagenomic projects, the bottleneck remains on the isolation of metagenomic DNA without substances.

Many specific methods for the isolation of prokaryotic DNA from soils have been published (Rajendhran and Gunasekaran, 2008). However, none of the methods reported hitherto are universally applicable and every type of soil sample requires optimization of DNA extraction methods (Harry et al., 1999; Lakay et al., 2007; Zhou et al., 1996). There is no standard procedure for the isolation and purification of soil metagenomic DNA of plant roots to evaluate microbial community diversity. In this study, we developed a standard procedure for the effective quantification and purification of metagenomic DNA from the soil around plant roots, amenable to PCRDGGE based analysis to evaluate microbial community diversity. The impacts of repeated sequential extractions on quality, quantity and composition of metagenome DNA were also evaluated.

\section{MATERIALS AND METHODS}

\section{Sample collection}

Soil samples were collected from Shanghai Academy of Agricultural Sciences Bai He Base, which is used to assess biosafety of new varieties of plants including transgenic plants. Twelve soil samples were taken from root systems in various crops, numbered RS1RS3 (rice), RS4-RS6 (corn), RS7-RS9 (Artemisia annua) and RS10-RS12 (tomato). In brief, soil samples were collected in sterile tubes $(50 \mathrm{ml})$ and immediately stored in liquid nitrogen. After being passed through a 20-mesh sieve, plant roots, animal debris and other debris in the soil samples were removed. Soil samples were separated into centrifuge tubes, $0.5 \mathrm{~g}$ for each tube. The tubes were then numbered and stored at $-70^{\circ} \mathrm{C}$ for later use.

\section{DNA isolation from soil samples}

Sample pickling liquors $(1.5 \mathrm{ml}$ of $40 \mathrm{mM}$ three carboxy methyl amino methane, 60 mMethylene diamine tetra-acetic acid(EDTA), $150 \mathrm{mMNaCl}, 0.5 \%$ TEEPOL, $1 \%$ polyvinylpolypyrrolidone (PVPP) at $\mathrm{pH}$ 9.5) was mixed with $0.5 \mathrm{~g}$ (wet weight) of soil. The mixture was then vortexed for $10 \mathrm{~min}$, and the supernatant was discarded, which was repeated three times. $70 \%$ ethanol $(1.5 \mathrm{ml})$ was added, and the solution was incubated on ice for $5 \mathrm{~min}$, slowly vortexed for $10 \mathrm{~min}$ and centrifuged for $5 \mathrm{~min}$ at $10000 \mathrm{~g}$.. This step of manipulation was also repeated three times. Glass beads ( $0.3 \mathrm{~g}$ quartz sand, a 4-mm diameter glass bead ) and $978 \mu \mathrm{L}$ of phosphate buffer ( $\mathrm{pH}$ 8.0) were added and the sample was vortexed for $5 \mathrm{~min}$. Lysozyme $(100 \mathrm{mg} / \mathrm{ml}, 50 \mu \mathrm{L})$ and proteinase $\mathrm{K}(20 \mathrm{mg} / \mathrm{ml}, 50 \mu \mathrm{L})$ were added and incubated for $10 \mathrm{~min}$ at $37^{\circ} \mathrm{C}$. Lysis buffer $(122 \mu \mathrm{L}$ of $1 \%$ sodium dodecyl sulphate(SDS), $40 \mathrm{mMTris}, 150 \mathrm{mMNaCl}, 60$ $\mathrm{mM}$ EDTA, 1\% PVP at $\mathrm{pH}$ 8.0) was added and vortexed for 5-20 min, centrifuged for $10 \mathrm{~min}$ at $12000 \mathrm{~g}$. The supernatant was transferred to centrifuge tube $(2 \mathrm{ml})$ containing $750 \mu \mathrm{L}$ of phenol: chloroform: isoamyl alcohol (25:24:1), and incubated on ice for 5 min, shaken well completely and centrifuged for $15 \mathrm{~min}$ at $16000 \mathrm{~g}$, $4^{\circ} \mathrm{C}$, this was repeated twice. The supernatant was transferred to a new centrifuge tube $(1.5 \mathrm{ml})$ containing an equal volume of chloroform: isoamyl alcohol (24:1), and incubated on ice for $5 \mathrm{~min}$ and was shaken fully, and then centrifuged for 15 min at $16000 \mathrm{~g}$, $4^{\circ} \mathrm{C}$, this was repeated twice. 
The supernatant was transferred to a new centrifuge tube $(1.5 \mathrm{ml})$ containing 0.1 volume of $5 \mathrm{M} \mathrm{NaCl}$ and 0.06 volume of polyethylene glycol and incubated overnight at room temperate and centrifuged for $15 \mathrm{~min}$ at $18000 \mathrm{~g}$. The supernatant was removed and the precipitation was resuspended in $50 \mu \mathrm{L}$ of double distilled water (ddH2O). The crude DNA was purified according to the instruction manual of the DNA purification kit produced by Shanghai Academy of Agricultural Sciences Biosafety Laboratory. The purified DNA was eluted into a collection tube by $50 \mu \mathrm{L}$ of ddH2O and stored at $20^{\circ} \mathrm{C}$.

Assessment of quality, quantity and composition of the metagenome DNA

The isolated genomic DNA was analyzed by $0.8 \%$ agarose gel electrophoresis. The results were photographed after ethidium bromide (EB) staining. DNA concentration was determined by NanoDrop® ND-1000 and DNA yield was calculated. To evaluate the purity of the extracted DNA, OD (optical density) values were measured at wavelengths of 230, 260 and $280 \mathrm{~nm}$ (A230, A260 and A280, respectively), and the ratios A260/A280 and A260/A230 were calculated. Absorption values of DNA solution were measured by full spectrum scan at a wavelength range of 220-320 nm. The average ratio of $\mathrm{A} 260 / \mathrm{A} 280$ was calculated for each set of triplicate samples, and used to estimate the purity of extracted nucleic acid: samples with mean A260/A280 of 1.8-2.0 were presumed to be free of contamination; those with A260/A280 < 1.8 were presumed to contain protein or other contaminants; and those with A260/A280 $>2.0$ were presumed to be due to the presence of RNA (RooseAmsaleget al., 2001).

\section{PCR amplification}

\section{PCR amplification primers}

Primers used in this paper include those specific for 16S rDNA of bacteria and $18 \mathrm{~S}$ rDNA of fungi. The bacterial primers were: $341 \mathrm{f}-$ GC, 5'-CGCCCGCCGCGCGCGGCGGGCGGGGCGGGGGCA CGGGGGGCCTACGGGAGGCAGCA-3', and 518R, 5'GTATTACCGCGGCTGCTGG-3'. The fungal primers were: NS7$\mathrm{GC}$,

CGCCCGCCGCGCCCCGCGCCCGTCCCGCCGCCCCCGCCC

CAGGCAATAACAGGTCTG-3'; and NS8, 5'TCCGCAGGTTCACCTACGGA-3'.

\section{PCR amplification reaction system}

Amplification was carried out in a $50-\mu \mathrm{L}$ reaction volume containing $1 \times$ buffer, $1 \mu \mathrm{L}$ of template (soil DNA), $200 \mathrm{nM}$ of both primers, 200 $\mathrm{mM}$ of each nucleotide, $2.5 \mathrm{mM} \mathrm{MgCl} 2$ and $1 \mathrm{U}$ of Taq DNA polymerase.

\section{PCR reaction parameters}

The 16s rDNA V3 section of bacteria and 18s rDNA V9 section of fungi were amplified using the denaturation, annealing, and polymerization times and temperatures as follows: $94^{\circ} \mathrm{C}$ for $5 \mathrm{~min}, 94^{\circ} \mathrm{C}$ for $30 \mathrm{~s}$, annealing for $45 \mathrm{~s}$ (annealing temperature for bacteria is $55^{\circ} \mathrm{C}$ and for fungi $50^{\circ} \mathrm{C}$ ), and $72^{\circ} \mathrm{C}$ for $45 \mathrm{~s}$, with 33 cycles. The final extension was at $72^{\circ} \mathrm{C}$ for $10 \mathrm{~min}$.

\section{Test for PCR products}

PCR products were electrophoresed in $1.5 \%$ agarose gels, and gels stained with EB and photographed.
Bacterial community composition assessed by DGGE based on DNA extracted from plant root

SoilDGGE was carried out using the DCode Universal Mutation Detection System (Bio-Rad), with a denaturing gradient of $30-60 \%$ (fungi) and $20-70 \%$ (bacteria) in a $7.5 \%$ polyacrylamide gel $(100 \%$ denaturant is defined as a mixture of $7 \mathrm{M}$ urea and $40 \%$ deionized formamide). The conditions for separation were: $15 \mu \mathrm{L}$ of PCR products were loaded per well and run for $10 \mathrm{~min}$ at $200 \mathrm{~V}$ and $16 \mathrm{~h}$ at $60 \mathrm{~V}$ in $0.5 \times \mathrm{TAE}$ buffer. After electrophoresis, gels were stained for $20 \mathrm{~min}$ in $400 \mathrm{ml}$ of EB $(0.25 \mu \mathrm{g} / \mathrm{ml})$, photographed in UV light with a Gel-Doc2000 imaging system (Bio-Rad) and banding patterns were analyzed using Quantity One (Bio-Rad).

\section{RESULTS}

\section{DNA extraction yields, size and purity}

Figure 1 and Table 1 shows the quantity and quality of extracted DNA from original soil samples. The total DNA extracted from different soil samples was about $20 \mathrm{~kb}$ in size, and some genomic DNA was degraded. From $1 \mathrm{~g}$ of soil sample, $>10 \mu \mathrm{g}$ of genomic DNA could be obtained and there was little difference among the DNA yield of soil samples.Figures 2 and 3 shows A260/A230 and A260/A280 ratios of genomic DNA extracted from different soil samples, respectively. A260/A230 of the pure nucleic acid was 1.820 , pure humus was 0.8 ; and the average A260/A230 of the genomic DNA extracted from different soil samples was 1.505 , which is close to the ratio of pure nucleic acids. A260/A280 of pure nucleic acids was 1.880; and the average A260/A280 of the genomic DNA extracted from different soil samples was 1.780 , which is close to the ratio of pure nucleic acids. The full spectrum scan of the extracted DNA at a wavelength range of 220-340 nm was shown in Figure 4. The absorption curves of the extracted DNA were consistent with pure nucleic acids. There was an absorption peak at wavelength $260 \mathrm{~nm}$ and an absorption valley at $230 \mathrm{~nm}$ (pure humus had an absorption peak at $230 \mathrm{~nm}$ ).

\section{Effect of contaminants in extracted DNA on the restriction enzyme operation}

Lambda DNA in the dilution of soil DNA was digested with restriction enzyme HindllI. The effect of potential restriction enzyme inhibitors (humus, metal ions and other pollutants) is shown in Figure 5. Restriction operation produced clear bands of digested lambda DNA, indicating that the restriction operation could be carried out in dilutions of soil sample DNA. The result of lambda DNA digested in 100-fold diluted soil sample DNA was identical with that in ddH2O.

The PCR amplification results of the extracted DNA are shown in Figure 6. Using extracted microbial genome DNA as template, $16 \mathrm{~S}$ rDNA in the bacterial $\mathrm{V} 3$ region was amplified using population-specific DGGE-PCR primers. Amplification results showed that the target fragment was 


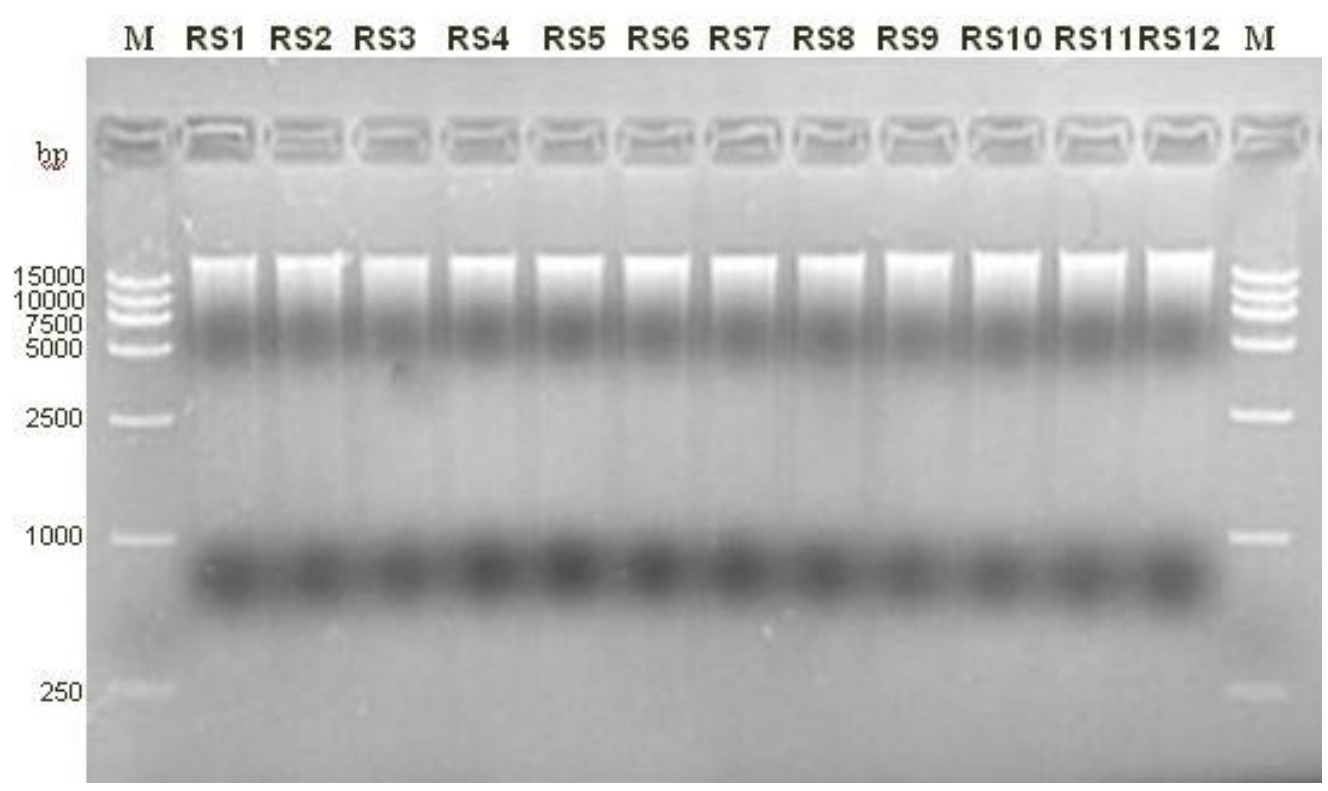

Figure 1.Total DNA from soil samples.M, DNA Marker;RS1-RS12, DNA extracted fromtwelve soil samples using the method.

Table 1.Crude DNA yield and ratios for soil samples.

\begin{tabular}{lccccc}
\hline Sample & DNA $(\mathbf{n g} / \boldsymbol{\mu L})$ & $\mathbf{A}_{\mathbf{2 6 0}}$ & $\mathbf{A}_{\mathbf{2 8 0}}$ & $\mathbf{A}_{\mathbf{2 3 0}}$ & Nucleic acid yield $(\boldsymbol{\mu} \mathbf{g} / \mathbf{g}$ soil) \\
\hline Pure nucleic acids $^{\mathrm{a}}$ & 98.12 & 1.962 & 1.042 & 1.077 & - \\
Pure humicacid $^{\mathrm{b}}$ & - & 0.972 & 0.769 & 1.215 & - \\
RS1 & 100.331 & 2.006 & 1.095 & 1.204 & 10.033 \\
RS2 & 102.427 & 2.048 & 1.146 & 1.323 & 10.243 \\
RS3 & 102.407 & 2.048 & 1.122 & 1.274 & 10.241 \\
RS4 & 102.643 & 2.053 & 1.151 & 1.336 & 10.264 \\
RS5 & 103.648 & 2.073 & 1.175 & 1.393 & 10.365 \\
RS6 & 104.150 & 2.083 & 1.187 & 1.422 & 10.415 \\
RS7 & 104.550 & 2.091 & 1.162 & 1.373 & 10.455 \\
RS8 & 105.477 & 2.110 & 1.194 & 1.447 & 10.548 \\
RS9 & 107.306 & 2.146 & 1.213 & 1.500 & 10.731 \\
RS10 & 109.908 & 2.199 & 1.262 & 1.620 & 10.991 \\
RS11 & 108.408 & 2.168 & 1.234 & 1.551 & 10.841 \\
RS12 & 110.980 & 2.220 & 1.282 & 1.669 & 11.098 \\
\hline
\end{tabular}

${ }^{\mathrm{a}}$, Pure nucleic acids $(\approx 0.1 \mathrm{mg} / \mathrm{ml})$; ${ }^{\mathrm{b}}$, pure humic acid $(\approx 0.8 \mathrm{mg} / \mathrm{ml})$.

amplified in all extracted DNA (Figure 6). Therefore, using the DNA extraction method described here, the microbial total DNA extracted from different soil samples could be amplified with the expected molecular size by the PCR operation and was suitable for molecular ecology studies.

DGGE analysis of microbial diversity in plant rhizosphere soil DNA extracts The PCR-DGGE banding profiles of soil bacterial and fungal communities in different plant rhizosphere soils showed many common bands present in all tested soils (Figure 7), suggesting that microbial species in soil samples could be easily lysed using the extraction procedures. The community profiles originating from the same plant rhizosphere soil resembled each other. However, there were significant differences in intensities and numbers of bands between different plant rhizosphere soils.

\section{DISCUSSION}

A soil DNA extraction method was established in this study. The extracellular DNA and humus were removed by the sample pre-treatment before cell lysis, and the 


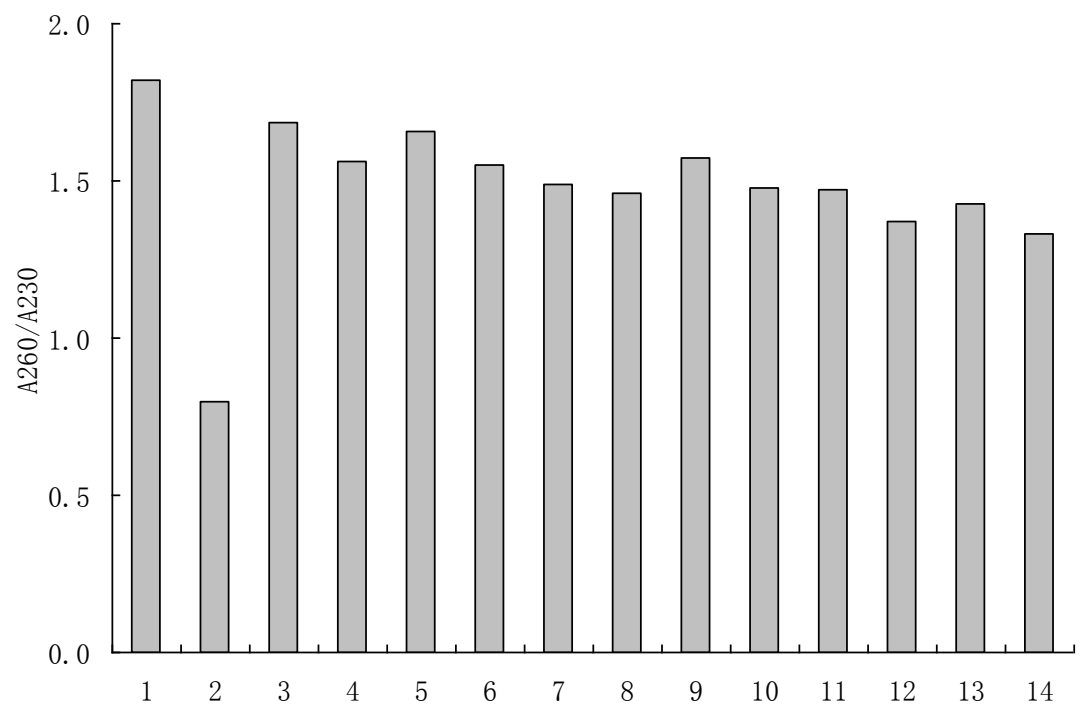

Figure 2. A260/230 ratio of nucleic acid obtained from soil samples. 1, Pure nucleic acids; 2, pure humic acid; 3-14, DNA extracted fromtwelve soil samples using the method.

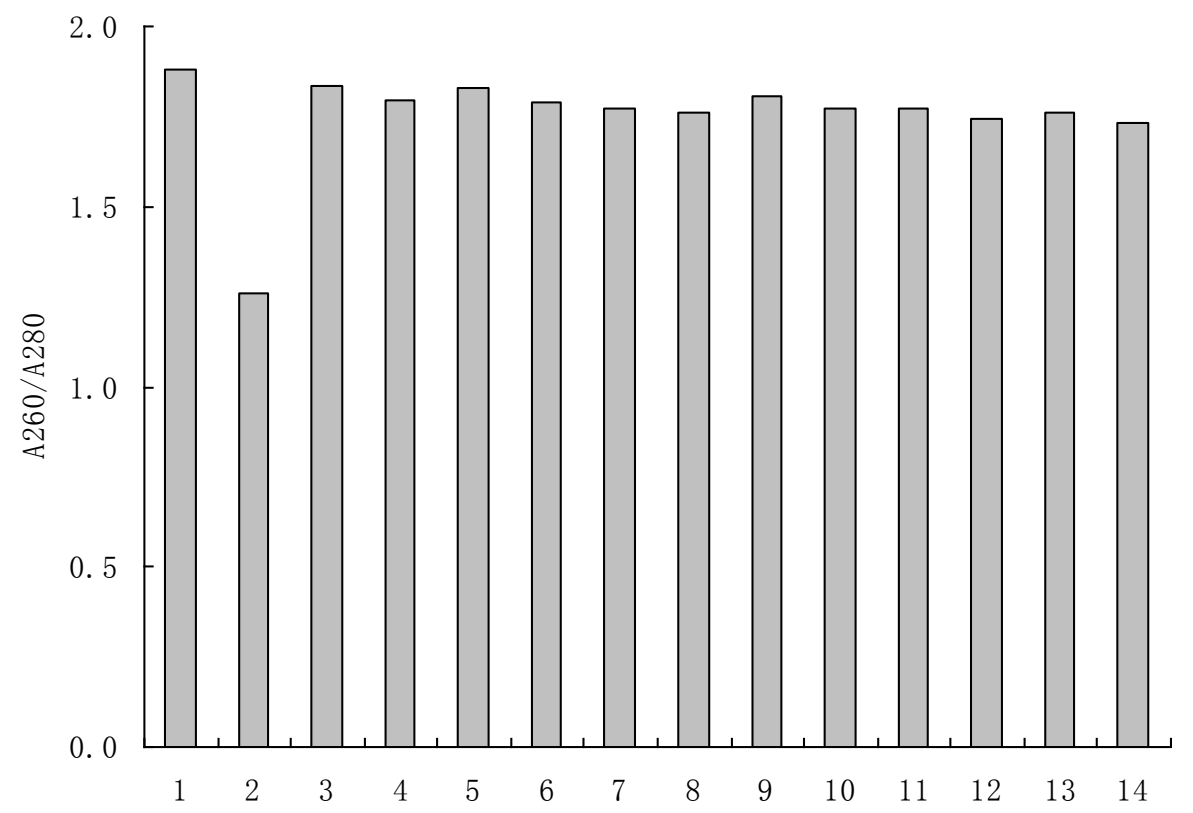

Figure 3. A260/280 ratio of nucleic acid obtained from soil samples. 1, Pure nucleic acids; 2, pure humic acid; 3-14, DNA extracted fromtwelve soil samples using the method.

difficulty of humus removal in the purification procedure was effectively avoided. With a three-dimensional structure, humus could combine other compounds to their active functional groups and absorb water, ions and organic molecules (Stevenson, 1976). Thus, all natural organic compounds can be bound or adsorbed on humus (Fortin et al., 2004). In addition, humus is similar to nucleic acids in physical and chemical characters. Therefore, humic acid compounds and nucleic acids will compete to bind the DNA precipitation or adsorption sites of the purification column (Harry et al., 2001). Most humus is soluble in alkaline solution, and the PVPP could inhibit the precipitation of humic acid. Purity of the soil sample DNA was improved by pretreatment of soil samples by 


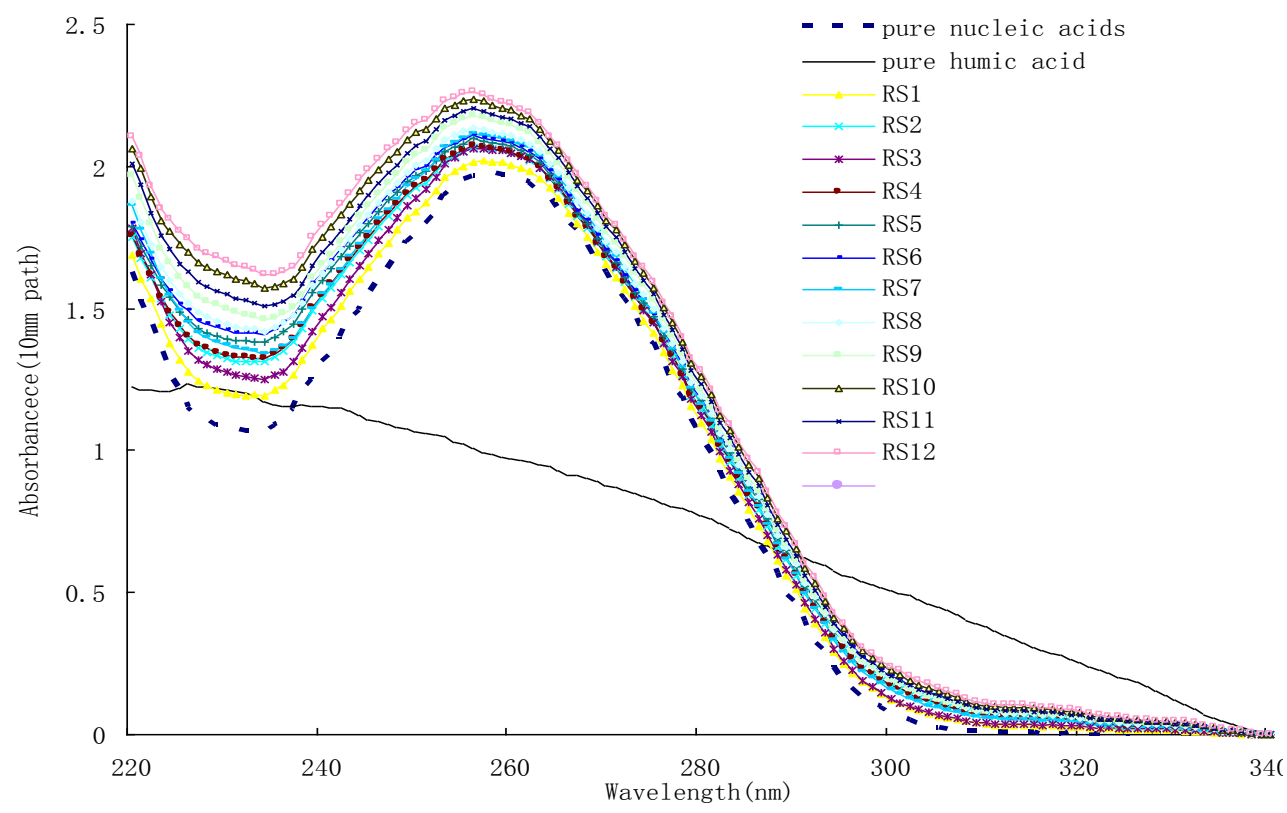

Figure 4. Absorbance spectra of nucleic acids obtained from soil samples. The absorbance spectra of pure humic acids in water $(1 \mathrm{mg} / \mathrm{mlml}$, scaled on $\mathrm{y}$-axis $)$ and pure nucleic acids $(0.1 \mathrm{mg} / \mathrm{m} / \mathrm{ml}$, DNA : RNA at 2:1, scaled on y-axis) are given for comparison.

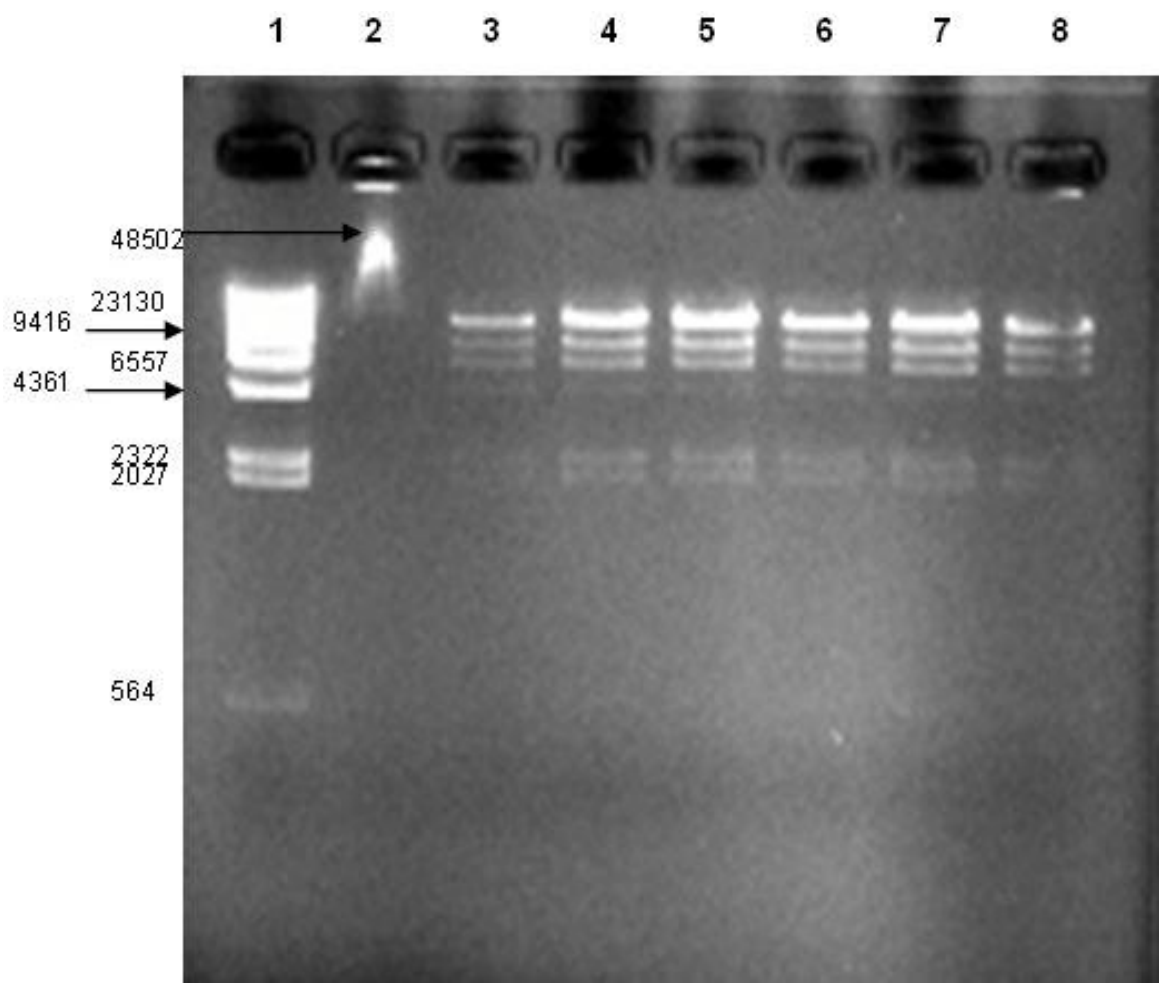

Figure 5. Restriction enzyme digestion patterns of lambda DNA plus dilutions of soil DNA. 1, Lambda DNA /HindIII DNA Mark (23130, 9416, 6557, 4361, 2322, 2027, 564 and $125 \mathrm{bp}$ ); 2, lambda DNA (48502 bp); 3, lambda DNA plus soil DNA (31 ml 1:50); 4, lambda DNA plus soil DNA (31 ml 1:100); 5, lambda DNA plus soil DNA (31 ml 1:200); 6, lambda DNA plus soil DNA (31 ml 1:300); 7, lambda DNA plus soil DNA (31 ml 1:400); 8, lambda DNA plus ddH2O (31 ml). 
(a)

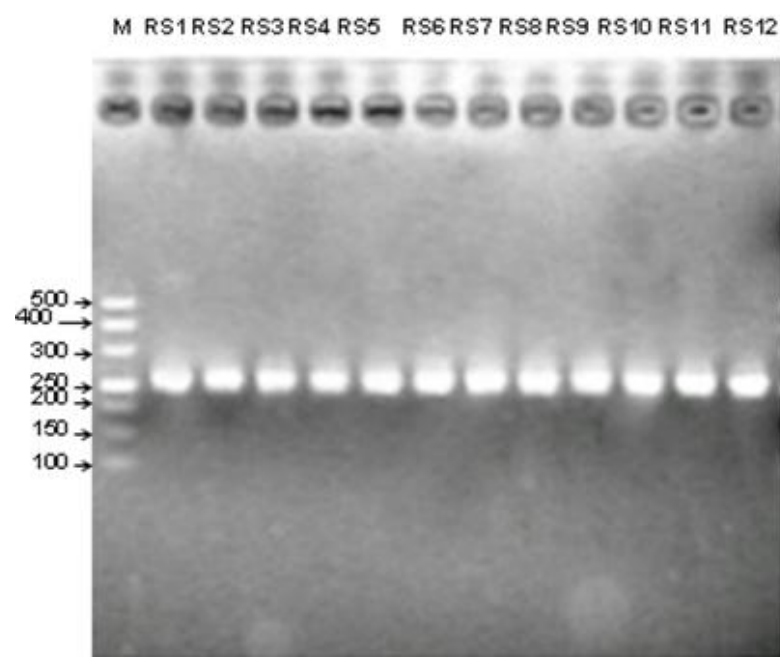

(b)

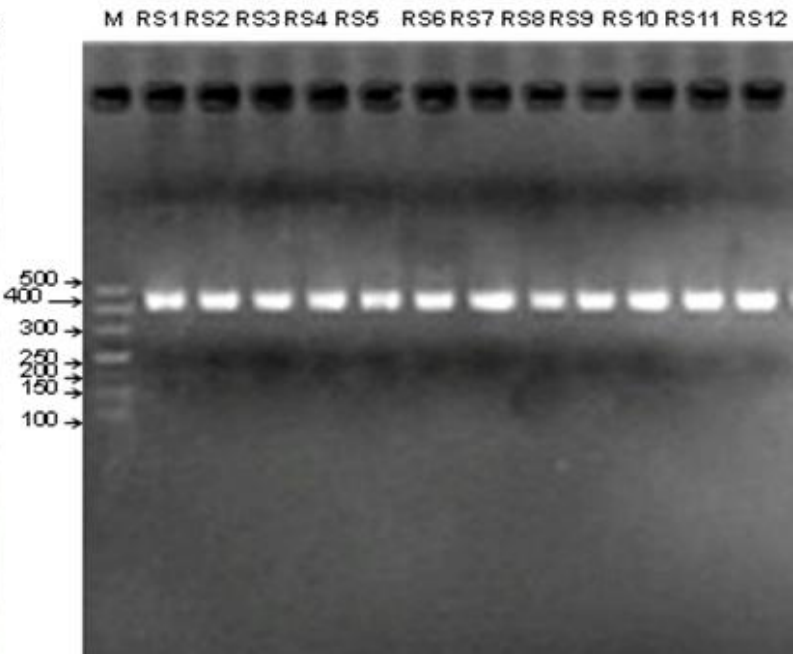

Figure 6.PCR amplification results.(a) Bacterial 16S rDNA; (b) fungal 18S rDNA.

(a)

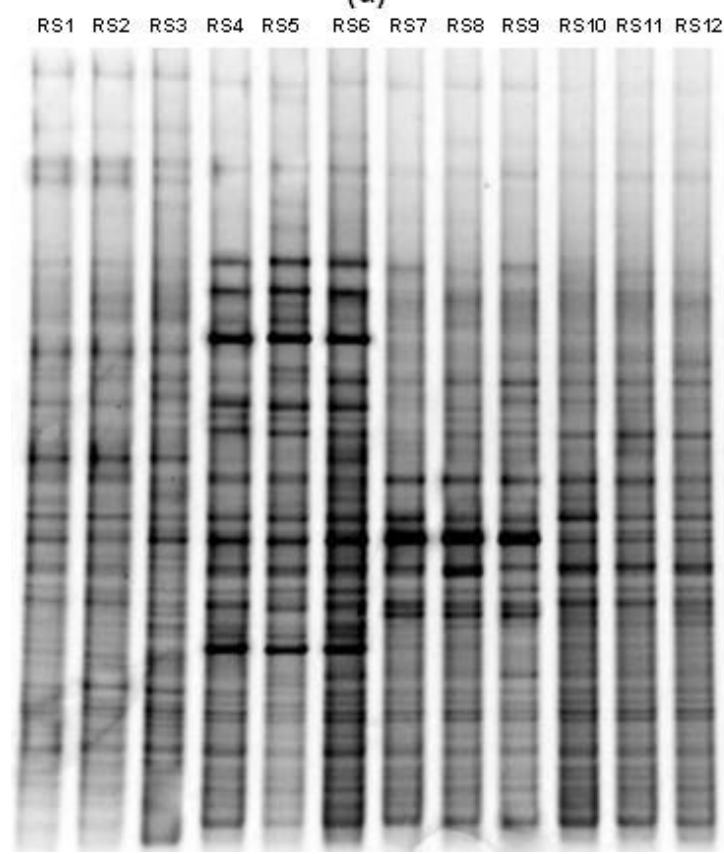

(b)

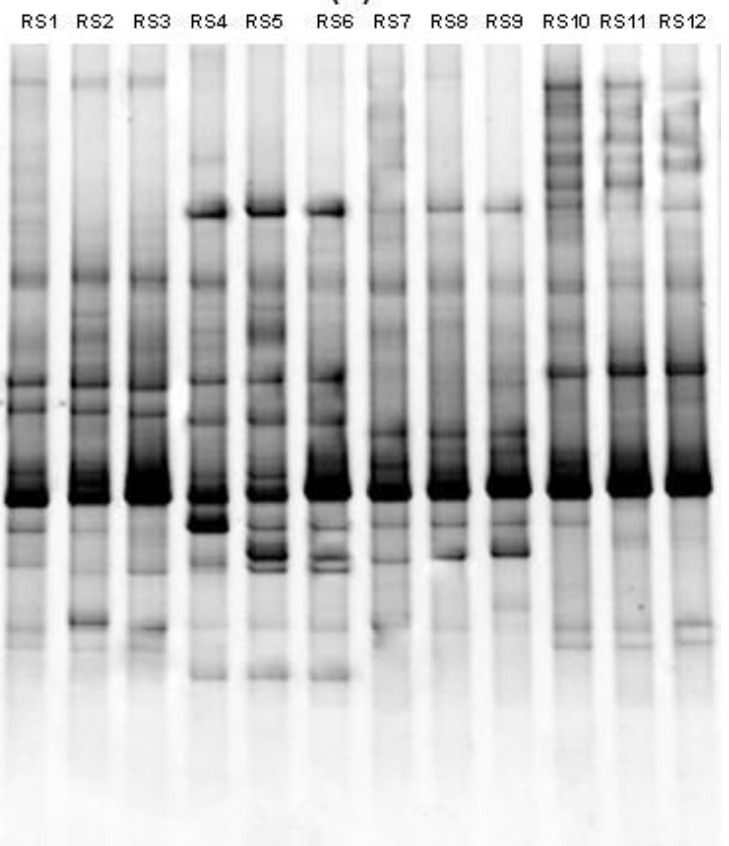

Figure 7. DGGE profiles for bacterial and fungal communities in soil samples: (a) bacterial $16 \mathrm{~S}$ rDNA, (b) fungal $18 \mathrm{~S}$ rDNA.

adding buffer containing alkaline PVPP and $70 \%$ ethanol to remove the humus prior to cell lysis. EDTA in alkaline buffer can combined with metal ions to form a complex and inhibit the activity of nuclease, to prevent DNA degradation in the following DNA extraction process. Pretreatment with $70 \%$ ethanol could effectively remove metal ions, salt and organic pollutants soluble in water. In addition, the pretreatment of vortexing was moderate in vibrant strength and would not cause cell rupture and DNA release in advance. Centrifugation at $12000 \mathrm{~g}$ for 30 min would not cause the loss of cells. In steps 3 and 4 , with proteinase $\mathrm{K}$ and lysozyme digestion, soil microbial cells were lysed by degradation of the peptidoglycan layer of the cell wall. Since the peptidoglycan layer is less substantial in Gram-negative than in Gram-positive bacteria (Gannon et al., 1992), this may cause initial swelling 
as a result of spheroplast formation. Cells were lysed by a combination of bead beating and SDS lysis method. A long bead-beating time increased the yield of genomic DNA however, it inevitably had a shearing effect on large fragments of genomic DNA. Crude DNA was purified by column purification after treatment as follows: phenolchloroform, phenol-chloroform-isoamyl alcohol and isoamyl alcohol. The fact that more than $10 \mu \mathrm{g} / \mathrm{g}$ of genomic DNA was extracted in all 12 soil samples indicated the combination method of lysis was effective in extracting sufficient genomic DNA. The efficiency of metagenomic DNA extraction for analysis of microbial diversity depended on whether the obtained DNA was representative of the microbial community.

Maximum absorption wavelengths of humus and protein were 230 and $280 \mathrm{~nm}$, respectively, while that of DNA was $260 \mathrm{~nm}$. Therefore, the purity of soil metagenomic DNA was assessed by the value of absorption ratios A260/A230 (DNA/humic acid) and A260/A280 (DNA/ protein). After purification, the average A260/A280 and A260/A230 ratios of the 12 soil samples were 1.780 and 1.505 , respectively, and the absorption curve was consistent with pure nucleic acids, indicating that humus, pigments and other contaminants in soil were effectively removed by this method, and that the purity of extracted DNA was close to the standard DNA.

If the humus together with adsorbed organic molecules were extracted, almost all the molecular biology methods would be affected, for example,DNA restriction enzyme digestion and PCR. The quality of the DNA extracted with the above protocol was first evaluated for its accessibility for restriction enzyme digestion of DNA. In the different dilutions of extracted DNA containing potential enzyme inhibitors, lambda DNA could be digested by the restriction enzyme HindlII, and the digested bands of lambda DNA were clear. The result of lambda DNA digested in 100-fold diluted soil sample DNA was identical with that in $\mathrm{ddH} 2 \mathrm{O}$, while DNA extracted by Tebbe and Vahjen (2001) needed to be diluted 1000 times in order to carry out digestion of lambda DNA (Tebbe and Vahjen, 2001). DNA extracted by Yeates (2001) needed 200-fold dilution to observe bands of digested lambda DNA (Yeateset al., 2001). Thus, the method of the present study to extract genomic DNA from soil samples effectively removed the restriction enzyme inhibitor, and molecular experiments associated with restricttion enzyme digesting could be conducted at certain dilutions. Subsequently, PCR of the DNA extracted with the above protocol was evaluated. The same DNA solution was used for amplification with a primer pair specific for PCR-DGGE, containing a GC-clamp at the 5 '-end of the forward oligonucleotide. Clear single bands were obtained using population-specific DGGEPCR primers to amplify $16 \mathrm{~S}$ rDNA in the bacterial V3 area and 18S rDNA in the fungal V9 area, indicating DNA by this method effectively removed the pollutants inhibiting PCR amplification. Furthermore, PCR produced amplicons with the expected molecular size suitable to be analyzed using a denaturing containing polyacrylamide gel for the microbial ecology composition. In summary, genomic DNA extracted by this approach was suitable for molecular ecology research (that is,restriction enzyme analysis, PCR and DGGE analysis), which is relevant to the effects of genetically modified crops on diversity of root microorganisms.

\section{Conclusion}

A genomic DNA extraction method was established to evaluate the effect of transgenic crops on soil microbial diversity in the rhizosphere. The results demonstrated the following: (i) More than $10 \mu \mathrm{g} / \mathrm{g}$ genomic DNA could be extracted from different soil samples, with fragment size about $20 \mathrm{~kb}$; (ii) the purity of genomic DNA extracted from different rhizosphere soil samples reached a high level, average ratios of A260/A230 and A260/A280 were 1.505 and 1.780 , respectively, and the absorption curve was consistent with pure nucleic acids; (iii) contamination of 100 -fold diluted soil sample DNA had no effect on the restriction enzyme reaction; (iv) the extracted soil genomic DNA from different rhizosphere soil samples was capable of population-specific DGGE-PCR; (v) the extracted soil DNA could be further used for PCR-based DGGE analysis of complex microbial communities. In concluding, the described method allows for efficient extraction of highly pure nucleic acids from soil, which is amenable to PCR-DGGE based analysis to evaluate microbial community diversity. Further studies may focus on investigating the effects of $\mathrm{Bt}$ rice on microbial communities in a flooded paddy soil.

\section{ACKNOWLEDGEMENTS}

This work was financially supported by Shanghai Agricultural Science Committee foundation of China, grant no.6-4 (2009) and 6-2(2011), Shanghai Agricultural Science Key Research Foundation, grant no.1-8 (2011), Shanghai Science and Technology Committee Key Foundation of China, grant no.10JC1413800, The Shanghai Academy of Agricultural Sciences, grant no. 2010(16), Shanghai Committee of Science and Technology, Shanghai Post doctoral Sustentation Fund, grant No. 13R21421000, China Postdoctoral Science Foundation, grant No. 2013M531197, and National Scientific and Technical key Program from Ministry of Science and Technology of China, Grant no. 2012ZX07101-009, International cooperation key program grant no.CS06-L10.

\section{REFERENCES}

Atwood L (2011). Genetically modified crops, agro-chemicals, and soil quality.Perspectives from Michigan's large-scale commercial farmers. Appetite. 56:518-518. 
Birch ANE, Griffiths BS, Caul S, Thompson J, Heckmann LH, Krogh PH, Cortet $J$ (2007). The role of laboratory, glasshouse and field scale experiments in understanding the interactions between genetically modified crops and soil ecosystems: A review of the ECOGEN project. Pedobiologia. 51: 251-260.

Borneman J, Triplett EW (1997). Rapid and direct method for extraction of RNA from soil. Soil Biol. Biochem. 29: 1621-1624.

Daudu CK, Muchaonyerwa P, Mnkeni PNS (2009).Litterbag decomposition of genetically modified maize residues and their constituent Bacillus thuringiensis protein (Cry1 Ab) under field conditions in the central region of the Eastern Cape.South Africa, Agriculture, Ecosyst. Environ. 134: 153-158.

Dunfield KE, Germida JJ (2001). Diversity of bacterial communities in the rhizosphere and root interior of field-grown genetically modified Brassica napus. FEMS Microbiol. Ecol. 38: 1-9.

Fortin N, Beaumier D, Lee K, Greer CW (2004). Soil washing improves the recovery of total community DNA from polluted and high organic content sediments. J. Microbiol. Methods. 56:181-91.

Gannon VPJ, King PK, Kim JY, Thomas EJ (1992). Rapid and sensitive Method for detection of shiga-like toxin-producing Escherichia coli in ground beef using the polymerase chain reaction. Appl. Environ. Microbiol. 58:3809-3815.

Garrity GM (2005). Bergey's manual of systematic bacteriology. Springer.

Groot AT, Dicke M (2002).Insect-resistant transgenic plants in a multitrophic context. Plant J. 31: 387-406.

Harry M, Gambier B, Bourezgui Y, Garnier-Sillam E (1999). Evaluation of purification procedures for DNA extracted from organic rich samples: interference with humic substances. Analusis. 27:439-42.

Heckmann LH, Griffiths BS, Caul S, Thompson J, Pusztai-Carey M, Moar WJ, Andersen MN, Krogh PH (2006). Consequences for Protaphoruraarmata (Collembola: Onychiuridae) following exposure to genetically modified Bacillus thuringiensis $(\mathrm{Bt})$ maize and non- $\mathrm{Bt}$ maize. Environ. Pollu. 142: 212-216.

Höss S, Nguyen HT, Menzel R, Pagel-Wieder S, Miethling-Graf R, Tebbe CC, Jehle JA, Traunspurger W (2011). Assessing the risk posed to free-living soil nematodes by a genetically modified maize expressing the insecticidal Cry3Bb1 protein. Sci. Total Environ. 409: 2674-2684.

James C (2013). Global Status of Commercialized Biotech/GM Crops: 2012. ISAAA Brief. 42:1-30.

Kowalchuk GA, Bruinsma M, Veen JA (2003). Assessing responses of soil microorganisms to GM plants. Trends Ecol. Evol. 18:403-410.
Lakay FM, Botha A, Prior BA (2007).Comparative analysis of environmental DNA extraction and purification methods from different humic acid-rich soils. J. Appl. Microbiol. 102: 265-273.

Li JT, Yang J, Chen DC, Zhang XL, Tang ZS (2007). An optimized mini-preparation method to obtain high-quality genomic DNA from mature leaves of sunflower. Genet. Mol. Res. 6:1064-1071.

Nunan N, Wu K, Young IM, Crawford JW, Ritz K (2003). Spatial distribution of bacterial communities and their relationships with the micro-architecture of soil. FEMS Microbiol. Ecol. 44: 203-215.

Rajendhran J, Gunasekaran P (2008). Strategies for accessing soil metagenome for desired applications. Biotechnol. Adv. 26: 576-590.

Robe P, Nalin R, Capellano C, Vogel TM, Simonet P (2003). Extraction of DNA from soil. Eur. J. Soil Biol. 39:183-190.

Roose-Amsaleg CL, Garnier-Sillam E, Harry M (2001).Extraction and purification of microbial DNA from soil and sediment samples.Appl. Soil Ecol. 18: 47-60.

Skinner FA, Jones PCT, Mollison JE (1952). A comparison of direct and plate counting techniques for the quantitative estimation of soil microorganisms. J. Gen. Microbiol. 6: 261-271.

Skyring GW, Quadling C (1969). Soil bacteria: comparisons of rhizosphere and nonrhizosphere populations, Can. J. Microbiol. 15:473-488.

Stevenson FJ (1976). Stability constants of $\mathrm{Cu}, \mathrm{Pb}$ and $\mathrm{Cd}$ complexes with humic acids. Soil Sci Soc Am J. 40: 665-72.

Tebbe CC, Vahjen W (1993). Interference of humic acids and DNA extracted directly from soil in detection and transformation of recombinant DNA from bacteria and yeast. Appl. Environ. Microbiol. 59: 2657-2665.

Williamson KE, Kan J, Polson SW, Williamson SJ (2011). Optimizing the indirect extraction of prokaryotic DNA from soils.Soil Biol. Biochem. 43:736-748. 